\title{
Diversity and dynamics of bacterial communities in early life stages of the Caribbean coral Porites astreoides
}

\author{
Koty H Sharp ${ }^{1,2}$, Dan Distel ${ }^{2}$ and Valerie J Paul ${ }^{1}$ \\ ${ }^{1}$ Smithsonian Marine Station, Fort Pierce, FL, USA and ${ }^{2}$ Ocean Genome Legacy, Ipswich, MA, USA
}

\begin{abstract}
In this study, we examine microbial communities of early developmental stages of the coral Porites astreoides by sequence analysis of cloned 16S rRNA genes, terminal restriction fragment length polymorphism (TRFLP), and fluorescence in situ hybridization (FISH) imaging. Bacteria are associated with the ectoderm layer in newly released planula larvae, in 4-day-old planulae, and on the newly forming mesenteries surrounding developing septa in juvenile polyps after settlement. Roseobacter clade-associated (RCA) bacteria and Marinobacter sp. are consistently detected in specimens of $P$. astreoides spanning three early developmental stages, two locations in the Caribbean and 3 years of collection. Multi-response permutation procedures analysis on the TRFLP results do not support significant variation in the bacterial communities associated with $\boldsymbol{P}$. astreoides larvae across collection location, collection year or developmental stage. The results are the first evidence of vertical transmission (from parent to offspring) of bacteria in corals. The results also show that at least two groups of bacterial taxa, the RCA bacteria and Marinobacter, are consistently associated with juvenile $\boldsymbol{P}$. astreoides against a complex background of microbial associations, indicating that some components of the microbial community are long-term associates of the corals and may impact host health and survival.

The ISME Journal (2012) 6, 790-801; doi:10.1038/ismej.2011.144; published online 24 November 2011
\end{abstract}

Subject Category: microbe-microbe and microbe-host interactions

Keywords: Porites astreoides; coral larvae; bacteria; mucus

\section{Introduction}

Corals are dynamic multi-domain assemblages consisting of the animal host, symbiotic dinoflagellates (zooxanthellae), bacteria, archaea, fungi and viruses (Knowlton and Rohwer, 2003). Recent research has identified diverse, complex bacterial assemblages in and on corals, including the carbonate skeleton, the internal tissue, and the surface mucopolysaccharide layer (reviewed in Rosenberg et al., 2007). Many coral-associated and reef-associated bacteria appear to serve beneficial roles for corals, including translocation of fixed nitrogen (Lesser and Farrell, 2004; Lesser et al., 2007; Olson et al., 2009), defense against coral pathogens (Ritchie, 2006; Nissimov et al., 2009; Rypien et al., 2010) and induction of coral larval settlement or metamorphosis (Negri et al., 2001; Tebben et al., 2011). Alteration of seawater chemistry and the resulting shifts in coralassociated bacterial community composition, growth rates or gene expression have been linked to coral diseases (Patterson et al., 2002; Frias-Lopez

Correspondence: KH Sharp, Eckerd College, 4200 54th Avenue South, St. Petersburg, FL 33711, USA.

E-mail: kotysharp@gmail.com

Received 2 February 2011; revised 6 September 2011; accepted 7 September 2011; published online 24 November 2011 et al., 2003, 2004; Kline et al., 2006) and bleaching (Kushmaro et al., 1997; Ben-Haim and Rosenberg, 2002). To identify the determinants of coral disease and to manage coral health in a changing marine environment, it is critical to establish whether corals maintain their associated microbiota across large geographical and temporal barriers and to identify how long-term, specific coral-bacterial associations are maintained in the marine environment.

The high bacterial diversity in corals makes it challenging to discern the extent to which coralbacterial associations are taxon-specific and stable. Recent applications of next-generation highthroughput sequencing methods have revealed highly diverse bacterial communities in many families of hard and soft corals (Sunagawa et al., 2009,2010 ), and research suggests that corals harbor specific assemblages of bacteria in the surface mucus layers and tissues (Rohwer et al., 2001, 2002; Barott et al., 2011; Sweet et al., 2011). Characterization of bacterial diversity in early life stages may be more tractable for identifying significant members of the coral-associated bacterial communities. In contrast to their adult counterparts, swimming larvae have not yet accumulated a high bacterial load from the surrounding environment or by feeding (Apprill et al., 2009; Sharp et al., 2010). Therefore, early life stages are likely to be more 
amenable to characterization and quantification. In addition, the simplicity of their microbial communities may facilitate distinguishing between bacteria closely associated with the host animal and other incidental bacteria.

Porites astreoides undergoes internal fertilization, broods its embryos in adult colonies, and then releases ciliated, swimming, non-feeding planula larvae into the water column (McGuire, 1998). Research on adult $P$. astreoides colonies has demonstrated that $P$. astreoides maintains specific bacterial assemblages that are distinct from that of seawater (Rohwer et al., 2002; Wegley et al., 2007). To date, nothing is known about the bacterial associates of the larvae upon release, throughout their planktonic period, and after settlement and metamorphosis into the first polyp of the colony. Using the early developmental stages of the coral P. astreoides, we present the first evidence of vertical bacterial transmission in corals. Though the inherited bacteria remain unidentified, our 16S rRNA gene sequence analysis shows that in P. astreoides, two groups of bacteria, Roseobacter clade-associated (RCA) bacteria and Marinobacter, are consistently detected in newly released larvae, across early development and in larval specimens collected from multiple locations in the Caribbean across a 4 year timespan. These groups of bacteria represent a consistent and specific component of the coral holobiont.

\section{Materials and methods}

Larval collection and rearing

Table 1 summarizes location and collection years of $P$. astreoides colony and larval collections during 2006-2009. Each year, collection efforts were timed around the new moon in the month of May. In all cases, $P$. astreoides colonies were collected at least 1 day before the new moon. The colonies released larvae each night for three to five nights. In the Florida Keys collections, $P$. astreoides colonies were collected from two near-shore habitats, Bahia Honda Bridge (2009) and Spanish Harbor Channel seawall (2006-2009). In 2008-2009, colonies were maintained in flow-through buckets in a nearshore

Table 1 Location and dates of Porites astreoides colony and larval collections during 2006-2009

\begin{tabular}{|c|c|}
\hline Date & Collection location \\
\hline May 2006 & $\begin{array}{l}\text { Spanish Harbor Channel, Florida Keys } \\
24.6491^{\circ} \mathrm{N}, 81.3194^{\circ} \mathrm{W}\end{array}$ \\
\hline April 2008 & $\begin{array}{l}\text { Carrie Bow Cay, Belize } \\
16^{\circ} 48.18^{\prime} \mathrm{N}, 88^{\circ} 04.93^{\prime} \mathrm{W}\end{array}$ \\
\hline May 2008 & $\begin{array}{l}\text { Spanish Harbor Channel, Florida Keys } \\
24.6491^{\circ} \mathrm{N}, 81.3194^{\circ} \mathrm{W}\end{array}$ \\
\hline May 2009 & $\begin{array}{l}\text { Spanish Harbor Channel, Florida Keys } \\
24.6491^{\circ} \mathrm{N}, 81.3194^{\circ} \mathrm{W}\end{array}$ \\
\hline May 2009 & $\begin{array}{l}\text { Bahia Honda Bridge, Florida Keys } \\
24.3918^{\circ} \mathrm{N}, 81.1719^{\circ} \mathrm{W}\end{array}$ \\
\hline
\end{tabular}

seagrass habitat (1-2 m depth) adjacent to the Mote Tropical Research Laboratory in Summerland Key throughout the larval collection period. Holes were cut in the sides and bottom of 5 gallon buckets and covered with nylon mesh ( $150 \mu \mathrm{m}$ pore diameter) to allow seawater to flow through. Colonies were placed within buckets with the lids in place. The buckets were placed lid-side down on the sand so that larvae were contained within the buckets upon release from the colonies. In the 2006 Florida Keys collections, colonies were maintained in flowthrough seawater tanks at the Mote Tropical Research Laboratory, and larvae were collected and maintained in tanks as described previously (Kuffner et al., 2006). In the 2008 Belize collection, $P$. astreoides colonies were collected from the reef flat in front of Carrie Bow Cay and maintained in flow-through seawater tanks piped directly from the adjacent near shore habitat. Larvae were collected in plastic buckets with nylon mesh $(150 \mu \mathrm{m}$ pore diameter). In all collections, the start of larval release was observed to be in the evening hours, ranging from 2000 hours until about midnight. Larval release continued throughout the early morning hours, and larvae were harvested around 0700-0800 hours each morning of collection.

For the 'newly released' time point, larvae were collected from the buckets within 5-10 min after $P$. astreoides colonies were first observed releasing larvae. This was done as early after release as possible to minimize the chances of bacterial uptake by the larvae from the seawater. For all other time points, larvae were collected each morning with turkey basters and glass Pasteur pipets. Larvae were maintained for the duration of early development in sealed, mesh-lined buckets in seagrass beds (Florida Keys) or in mesh-lined buckets in flow-through seawater (Belize) until fixation for observation on the microscope. In both locations, larvae were picked from the buckets each morning with glass Pasteur pipets and moved to new buckets in the seawater to reduce sedimentation buildup and fouling in the buckets. In addition, untreated glass slides were placed in the collection buckets so that $P$. astreoides larvae could attach to the slides and metamorphose into juvenile polyps.

Fluorescence in situ hybridization (FISH) and microscopy analysis

Swimming planula larvae and polyps settled on glass microscope slides were prepared from every collection and location. All samples were rinsed three times in $0.22 \mu \mathrm{m}$ filter sterilized seawater (FSW), either in microfuge tubes (planulae) or by dunking the glass slides sequentially into three $50 \mathrm{ml}$ polypropylene tubes of FSW (settled polyps). Rinsed planulae were then fixed in paraformaldehyde ( $4 \%$ in FSW) overnight at $4{ }^{\circ} \mathrm{C}$ and transferred to $70 \%$ ethanol/DI-water for long-term storage at $-20^{\circ} \mathrm{C}$. Slides were submerged in $4 \%$ paraformaldehyde in 
$50 \mathrm{ml}$ polypropylene tubes and fixed overnight at $4{ }^{\circ} \mathrm{C}$. The $4 \%$ paraformaldehyde was discarded, and the tube was filled with $70 \%$ ethanol/DI-water for long-term storage at $-20^{\circ} \mathrm{C}$. Samples were fixed and stored on the day of collection as described above. FISH was performed on fixed whole larvae in $0.7 \mathrm{ml}$ microfuge tubes or on microscopy slides with hybridization buffer $(0.9 \mathrm{M} \mathrm{NaCl}, 20 \mathrm{mM}$ Tris- $\mathrm{HCl}$ ( $\mathrm{pH} 7.4$ ) and $0.01 \%$ sodium dodecyl sulfate) containing $35 \%$ formamide for $2 \mathrm{~h}$ at $46{ }^{\circ} \mathrm{C}$. Samples were probed either with a suite of equimolar general eubacterial probes, EUB338I (5'-GCT GCC TCC CGT AGG AGT-3'), EUB338II (5'-GCA GCC ACC CGT AGG TGT-3') and EUB338III (5'-GCT GCC ACC CGT AGG TGT-3'); or a negative control probe, EUBNON (5'-ACT CCT ACG GGA GGC AGC-3') (Loy et al., 2003). Probes were ordered as CY3-end-labeled oligonucleotides (Integrated DNA Technologies, Coralville, IA, USA). All probes were added to hybridization buffer at a final concentration of $5 \mathrm{ng} \mathrm{l}^{-1}$. After hybridization, the hybridization buffer was removed from the samples. Samples were incubated in wash buffer $(0.7 \mathrm{M} \mathrm{NaCl}, 20 \mathrm{mM}$ Tris-HCl (pH 7.4) and $50 \mathrm{~mm}$ EDTA, $0.01 \%$ sodium dodecyl sulfate) for $20 \mathrm{~min}$ at $48{ }^{\circ} \mathrm{C}$. The samples were rinsed with Milli-Q water and mounted in VectaShield (Vector Labs, Burlingame, CA, USA). Slides were visualized on an LSM510 laser scanning confocal microscope (Zeiss, Jena, Germany). Larvae from each of the three developmental stages of interest were examined for each of the collection dates and locations.

\section{Nucleic acid extraction}

Individual larvae or individual polyps picked with a sterile pipet tip from the microscope slides were rinsed three times in FSW, placed in a microfuge tube containing RNALater (Ambion, Foster City, CA, USA) and stored frozen at $-20^{\circ} \mathrm{C}$ until DNA extraction. Genomic DNA was extracted from the samples using the following protocol, adapted from Preston et al. (1996). RNALater was removed from the samples and replaced with $1 \mathrm{mg} \mathrm{ml}^{-1}$ lysozyme/TE $(10 \mathrm{mM}$ Tris-HCl, $1 \mathrm{~mm}$ EDTA, pH 8.0), and the samples were incubated at $37^{\circ} \mathrm{C}$ for $30 \mathrm{~min}$. Proteinase $\mathrm{K}$ was added to a final concentration of $0.5 \mathrm{mg} \mathrm{ml}^{-1}$, and the sample was incubated at $55^{\circ} \mathrm{C}$ for $30-45 \mathrm{~min}$, until the solution was transparent, and then the sample was boiled for $60 \mathrm{~s}$. Nucleic acid extraction was performed using the DNEasy bacterial DNA kit (Qiagen, Valencia, CA, USA) starting at step 4 of the manufacturer's recommended protocol with the addition of ethanol. Because of the small amount of starting material (single planula or polyp), final elution volume was reduced to $50 \mu \mathrm{l}$.

16S rRNA gene library construction

PCR with bacterial domain specific primers 27f ( $5^{\prime}$-AGAGTTTGATCMTGGCTCAG-3') and 1492r
(5'-TACGGYTACCTTGTTACGACTT-3') was performed on DNA from a newly released larva from the May 2006 Florida Keys collection, a 4-day-old planula from the May 2008 Florida Keys collection and an 11-day-old polyp from the May 2008 Florida Keys collection with Phusion HF polymerase (Finnzymes/ThermoFisher Scientific, Waltham, MA, USA) using the following thermal cycling profile: initial denaturation $\left(3 \mathrm{~min}\right.$ at $\left.95^{\circ} \mathrm{C}\right)$; 35 cycles of denaturation $\left(30 \mathrm{~s}\right.$ at $\left.95^{\circ} \mathrm{C}\right)$, annealing $\left(1 \mathrm{~min}\right.$ at $\left.56^{\circ} \mathrm{C}\right)$ and elongation $\left(1 \mathrm{~min}\right.$ at $\left.72^{\circ} \mathrm{C}\right)$; and a final extension step $\left(7 \mathrm{~min}\right.$ at $\left.72^{\circ} \mathrm{C}\right)$. The resulting amplicons were ligated into pCR Blunt vector (Invitrogen Life Technologies, Carlsbad, CA, USA) by incubation with $1 \mu \mathrm{l}$ T4 DNA ligase $\left(400 \mathrm{U}^{-1} \mathrm{l}^{-1}\right.$ ) at $16^{\circ} \mathrm{C}$ for $1 \mathrm{~h}$. A volume of of $3 \mu \mathrm{l}$ of the ligation product was used to transform competent Escherichia coli C3019 cells using the manufacturer's suggested transformation protocol (New England Biolabs, Ipswich, MA, USA). Transformants were selected on LB-Kanamycin plates topspread with $50 \mathrm{ng} \mathrm{ml}^{-1} \mathrm{X}$-gal (5-bromo-4-chloro-3indolyl- $\beta$-D-galactopyranoside). Inserts were amplified from white colonies (transformants) picked from the selective plates in 96-well format PCR, with plasmid-specific primers (M13f: 5'-GTAAAAC GACGGCCAG-3'; M13r: 5'-CAGGAAACAGCTAT GAC- $3^{\prime}$, Invitrogen). PCR products of the expected size ( $\sim 1400 \mathrm{bp})$ were obtained from at least 96 colonies picked from each clone library, and each insert was sequenced unidirectionally with singlepass coverage. Sequence data were edited manually using Sequencher software (GeneCodes Corp., Ann Arbor, MI, USA), analyzed in SeqMan (DNAStar, Madison, WI, USA) and compared with databases by using blastn on BLAST (Altschul et al., 1990) and the Ribosomal Database Project (Cole et al., 2003). These sequence data have been submitted to the GenBank databases under accession numbers JN694776-JN694979.

\section{Fragment length analysis}

Terminal restriction fragment length polymorphism (TRFLP) analysis was performed on PCR amplification products generated, using DNA from each of 20 collected $P$. astreoides early life stage specimens from the 2006-2009 collections, in a PCR reaction with 5'-FAM (carboxyfluorescein)-labeled general bacterial domain specific primer $27 \mathrm{f}$ and unlabeled general bacterial domain specific primer 1492r, with the following thermal cycling profile: initial denaturation $\left(3 \mathrm{~min}\right.$ at $95^{\circ} \mathrm{C}$ ); 35 cycles of denaturation $\left(30 \mathrm{~s}\right.$ at $\left.95^{\circ} \mathrm{C}\right)$, annealing $\left(1 \mathrm{~min}\right.$ at $\left.56^{\circ} \mathrm{C}\right)$ and elongation ( $1 \mathrm{~min}$ at $\left.72^{\circ} \mathrm{C}\right)$; and a final extension step $\left(7 \mathrm{~min}\right.$ at $\left.72^{\circ} \mathrm{C}\right)$. This set of samples included specimens (though not the same individual specimens) from the collection locations and years corresponding to the three samples used for clone library construction. FAM-labeled PCR products were purified using the Qiaquick PCR purification 
kit (Qiagen). The purified PCR products were digested with the enzymes HhaI, MseI or RsaI (New England Biolabs) in separate reactions. PCR product (400 ng) was digested with $10 \mathrm{U}$ of enzyme in $1 \times$ buffer in a final volume of $50 \mu \mathrm{l}$, according to manufacturer's suggested protocol. Samples were incubated at $37^{\circ} \mathrm{C}$ for $2 \mathrm{~h}$, followed by $20 \mathrm{~min}$ at $65{ }^{\circ} \mathrm{C}$ for heat inactivation of the enzyme.

A volume of $1 \mu \mathrm{l}$ of each sample was prepared for capillary electrophoresis by addition of $0.15 \mu \mathrm{l}$ of MapMarker 1000 size standard (BioVentures, Inc., Murfreesboro, TN, USA) and $10 \mu \mathrm{l}$ of Hi-Di formamide (Applied Biosystems Inc., Foster City, CA, USA). MapMarker 1000 is an X-Rhodamine-labeled size standard with 23 single-stranded bands at 50, $75,100,125,150,200,250,300,350,400,450,475$, $500,550,600,650,700,750,800,850,900,950$ and $1000 \mathrm{bp}$. Samples were then heat denatured at $98{ }^{\circ} \mathrm{C}$ for $5 \mathrm{~min}$ before electrophoresis, which was performed on an Applied Biosystems model 3730xl Genetic Analyzer with a 96-capillary array that is $50 \mathrm{~cm}$ in length and filled with POP-7 polymer. The following parameters were used for analysis as follows: oven temperature, $63^{\circ} \mathrm{C}$; pre-run voltage, $15.0 \mathrm{kV}$; pre-run time, $180 \mathrm{~s}$; injection voltage, $1.6 \mathrm{kV}$; injection time, $60 \mathrm{~s}$; run voltage, $15.0 \mathrm{kV}$ and run time, $3000 \mathrm{~s}$. Using GeneMapper 4.0 (Applied Biosystems, Madison, WI, USA), the lengths of the fluorescently labeled fragments were determined by comparison with the MapMarker 1000 size standard using the local Southern algorithm and a peak amplitude threshold set at $50 \mathrm{rfu}(<1 \%$ of the maximum peak amplitude) for all dyes. Fragment analysis was performed between the range of $50 \mathrm{bp}$ and $800 \mathrm{bp}$, within the linear range of internal size standards. To correct for differential migration of X-Rhodamine-labeled standards and the FAM-labeled fragments, a second order equation describing the relationship between actual migration distance values of X-Rhodamine-labeled and FAM-labeled size standards of the same size was calculated (DNA Core Sequencing Facility, University of Illinois, Urbana, IL, USA) and used to transform the fragment migration values.

Predicted terminal restriction fragment lengths (T-RFs) of cloned sequences were obtained using in silico digestion on Sequencher (Gene Codes Corp.) and compared with Microbial Community Analysis III (MiCA3) (Shyu et al., 1997). Profiles of environmental samples were compared with the predicted clone fragment lengths to score presence of bacterial taxa in specimens. A taxon was scored as present if two criteria were fulfilled as follows: (1) the predicted fragment length matched the actual fragment length within $2 \mathrm{bp}$ and (2) at least two out of three of the restriction enzyme digests yielded a positive identification of the predicted fragment length of a clone from the sample.

Multi-response permutation procedures (MRPP) analysis was used to determine variation of T-RF profiles among samples, based on the characters of collection year (2006, 2008 and 2009); collection location (Belize or Florida Keys) and developmental stage (newly released, swimming planula or settled polyp). Variables that showed potential significant differences were subjected to pairwise comparisons with Fisher's exact test with false discovery rate correction (Storey, 2002) to determine which peaks resulted in the significant clustering in the MRPP analysis.

\section{Results}

FISH with bacterial domain-specific probes reveals the presence of bacterial cells at the base of the ectodermal cell layer in newly released P. astreoides larvae (Figures 1a-c). The micrographs in Figure 1 are representative of hundreds of larvae examined during 4 years of larval collection from P. astreoides colonies from Spanish Harbor and Bahia Honda in the Florida Keys and from Carrie Bow Cay in Belize. Of all of the larvae imaged, $100 \%$ of the larvae contained bacteria at the base of the ectodermal layer, though the density of bacteria was variable, ranging from dozens to hundreds of detectable bacterial cells in each larva. FISH images also indicated that bacteria were present in the coral throughout subsequent early development, settlement and metamorphosis (Figures 1d-i). In the newly released planulae and in planulae that have been exposed to seawater for 4 days, bacteria are present between cells of the larval ectoderm layer. After larval attachment, settlement and metamorphosis, bacteria were detected around the mesenteries surrounding the developing septa of the juvenile polyps.

Clone library construction was done from an individual of each stage: newly released larva, 4-day-old larva and 11-day-old settled juvenile. Samples were not pooled so that individual variation would be preserved. A total of 150 bacterial $16 \mathrm{~S}$ rRNA gene sequences were obtained. Though $>96$ products were cloned and sequenced from each stage, many of the sequenced clones matched most closely to eukaryotic $18 \mathrm{~S}$ rRNA or chloroplast $16 \mathrm{~S}$ rRNA gene sequence (GenBank/NCBI(National Center for Biotechnology Information)). The clones that appeared to be affiliated with eukaryotic sequences were removed from analysis, and only clones with similarity to bacterial 16S rRNA gene sequences were analyzed. In the newly released larva, only two sequences appeared to come from coral 18S rRNA or Symbiodinium chloroplast sequence, and 4-day-old larva had six sequences total that appeared to be from eukaryotic sources. In contrast, of the 123 clones originally picked for sequencing from the 11-day-old settler, 84 of the clones contained eukaryotic sequences. Shown in Table 2 are the percent sequence similarities of the bacterial cloned sequences, based on the blastn algorithm against the nucleotide database at NCBI (http://blast.ncbi.nlm. 


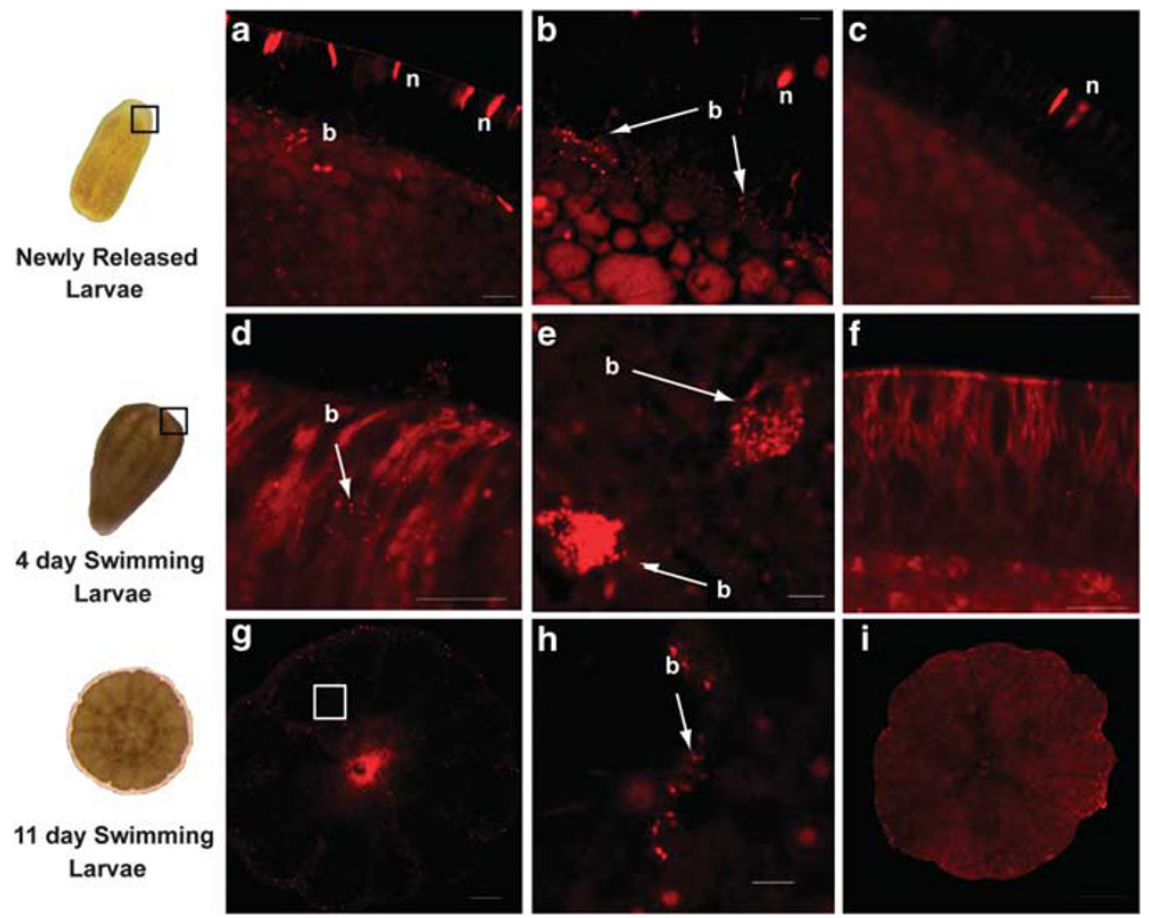

Figure 1 Bacteria in ectoderm and on the surface of $P$. astreoides early life stages. Hybridization of general eubacterial probes (EUB338) to bacterial cells in P. astreoides larvae is imaged by confocal microscopy. (a) Newly released larvae contain bacterial cells at the base of the ectoderm layer, shown by hybridization to the general eubacterial probe CY3-EUB338 (red). Bar $=20 \mu \mathrm{m}$. b, bacterial cell; n, nematocyst. (b) High magnification image of the bacterial cells at the base of the ectoderm. Bar $=10 \mu \mathrm{m}$. (c) The negative control probe, EUBNON, shows no probe binding in the ectoderm. Bar $=20 \mu \mathrm{m}$. (d) CY3-EUB338 (red) hybridizes to bacterial cells in the ectoderm layer in a 4-day-old planula. The larva also has bacterial aggregates on its surface, likely in mucus. Bar $=20 \mu$ m. (e) High magnification image of the surface of the planula shows bacterial aggregates hybridized with the EUB338 probe. Bar $=10 \mu \mathrm{m}$. (f) Negative control probe (EUBNON) shows no binding to cells within the ectoderm layer. Bar $=20 \mu \mathrm{m}$. (g) In an optical cross-section of a juvenile P. astreoides polyp $24 \mathrm{~h}$ after settlement, bacterial cells are present within tissue along the developing septa of the polyp, as shown in high magnification images $(\mathbf{h}$; $B a r=10 \mu \mathrm{m}$ ). (i) EUBNON probe shows no signal in a juvenile polyp. Bar $=5 \mu \mathrm{m}$.

nih.gov/) across $500 \mathrm{bp}$ sequence $(n=58$ for newly released larvae; $n=53$ for 4 day and $n=39$ for 11 day old) and the frequency of ribotypes present in clone libraries generated from each of the three types of samples. Ribotypes were named based on the most closely affiliated 16S rRNA gene sequences. The broad taxonomic groups common to the libraries from all three stages were $\gamma$-proteobacteria (order Alteromonadales, Oceanospirillales, Vibrionales), $\alpha$-proteobacteria (orders Rhodobacterales, Rhizobiales) and $\varepsilon$-proteobacteria (order Campylobacterales). Some ribotypes are present across all three libraries of cloned sequences, representing the $\gamma$-proteobacterial orders Oceanospirillales (genera Oceanospirillum and Thalassomonas) and Alteromonadales (genus Marinobacter) and RCA bacteria from the $\alpha$-proteobacterial order Rhodobacterales (genera Roseobacter, Roseivivax, Roseovarius and Rhodobacter). In addition, the library from the newly released larva consists of sequences affiliated with sequences from known animal-associated genera including Staphylococcus, Streptococcus and Haemophilus.

Sequences from this study were binned into six categories based on the origin of the sequences with the highest sequence similarity (GenBank and
Ribosomal Database Project): coral mucus; coral disease bands; seawater; other marine organisms; terrestrial environments and animal gut tracts. In both the 4-day-old and 11-day-old specimens, most of the cloned sequences $(\sim 90 \%$ and $60 \%$, respectively) fell into the coral mucus and coral disease band categories (Figure 2). In the newly released larva, a majority of the sequenced clones $(\sim 70 \%)$ had the highest similarity to sequences representing bacteria previously recovered from the mammalian digestive tracts. Specimens from each stage also included sequences affiliated with bacteria associated with marine invertebrates and dinoflagellates and other free-living marine bacteria.

TRFLP analysis was used to survey the collection of early developmental stage $P$. astreoides specimens, representing 4 years of collection, three collection locations and several time points throughout early development. Specimens with location, year and developmental stage corresponding to the samples used for clone library construction were included in the RFLP analysis to cross-reference fragment lengths with cloned sequences. A total of 80 unique T-RFs were observed using the restriction enzyme HhaI. There were 81 unique T-RFs observed in the MseI restriction 
Table 2 Bacteria present in early developmental stages of Porites astreoides

\begin{tabular}{|c|c|c|c|c|c|}
\hline \multirow{13}{*}{$\begin{array}{l}\text { Newly Released } \\
n=58 \text { clones }\end{array}$} & 98 & Alteromonadales & Coral mucus & 10 & 17 \\
\hline & 98 & Rhodobacterales & Coral disease bands & 6 & 10 \\
\hline & 99 & Lactobacillales & Mammalian gut & 14 & 24 \\
\hline & 98 & Lactobacillales & Terrestrial & 2 & 3 \\
\hline & 99 & Lactobacillales & Mammalian gut & 1 & 2 \\
\hline & 99 & Bacillales & Mammalian gut & 2 & 3 \\
\hline & 99 & Bacillales & Terrestrial & 1 & 2 \\
\hline & 98 & Bacillales & Mammalian gut & 1 & 2 \\
\hline & 100 & Pseudomonadales & Mammalian gut & 4 & 7 \\
\hline & 100 & Pseudoalteromonas & Mammalian gut & 2 & 3 \\
\hline & 100 & Pasteurellales & Mammalian gut & 11 & 19 \\
\hline & 99 & Flavobacteriales & Mammalian gut & 3 & 5 \\
\hline & 99 & Neisseriales & Mammalian gut & 1 & 2 \\
\hline
\end{tabular}

$\%$ Sequence similarity Affiliation Source $\quad$ Number of clones Total clones

\begin{tabular}{|c|c|c|c|c|c|}
\hline \multirow{17}{*}{$\begin{array}{l}4 \text { day } \\
n=53 \text { clones }\end{array}$} & 98 & Oceanospirillales & Coral Mucus & 21 & 40 \\
\hline & 99 & Oceanospirillales & Coral Mucus & 2 & 4 \\
\hline & 99 & Oceanospirillales & Coral Mucus & 1 & 2 \\
\hline & 96 & Oceanospirillales & Coral Disease & 1 & 2 \\
\hline & 100 & Oceanospirillales & Coral Mucus & 1 & 2 \\
\hline & 97 & Oceanospirillales & Dinoflagelllate & 1 & 2 \\
\hline & 97 & Rhodobacterales & Coral Mucus & 6 & 11 \\
\hline & 95 & Rhodobacterales & Coral Mucus & 2 & 4 \\
\hline & 94 & Rhodobacterales & Coral Disease & 1 & 2 \\
\hline & 99 & Rhodobacterales & Coral Mucus & 1 & 2 \\
\hline & 99 & Rhodobacterales & Coral Disease & 1 & 2 \\
\hline & 96 & Rhodobacterales & Dinoflagellate & 1 & 2 \\
\hline & 94 & unclass. $\alpha$-proteobacteria & Sponge & 1 & 2 \\
\hline & 98 & Alteromonadales & Coral Disease & 7 & 13 \\
\hline & 99 & Alteromonadales & Coral Mucus & 1 & 2 \\
\hline & 99 & Vibrionales & Seawater & 1 & 2 \\
\hline & 97 & Bdellovibrionales & Seawater & 1 & 2 \\
\hline
\end{tabular}

$\%$ Sequence similarity Affiliation Source Number of clones \% Total clones

\begin{tabular}{|c|c|c|c|c|c|}
\hline \multirow{25}{*}{$\begin{array}{l}11 \text { day } \\
n=39 \text { clones }\end{array}$} & 97 & Oceanospirillales & Coral Mucus & 1 & 3 \\
\hline & 99 & Oceanospirillales & Coral Mucus & 1 & 3 \\
\hline & 95 & Oceanospirillales & Seawater & 2 & 5 \\
\hline & 93 & Oceanospirillales & Sea Cucumber Disease & 1 & 3 \\
\hline & 98 & Rhodobacterales & Coral Disease & 3 & 8 \\
\hline & 95 & Rhodobacterales & Coral Mucus & 2 & 5 \\
\hline & 99 & Rhodobacterales & Coral Disease & 3 & 8 \\
\hline & 95 & Rhizobiales & Coral Mucus & 1 & 3 \\
\hline & 100 & unclass. $\alpha$-proteobacteria & Coral Mucus & 2 & 5 \\
\hline & 98 & Alteromonadales & Coral Mucus & 1 & 3 \\
\hline & 98 & Alteromonadales & Seawater & 1 & 3 \\
\hline & 99 & Alteromonadales & Seawater & 1 & 3 \\
\hline & 99 & Alteromonadales & Dinoflagellates & 3 & 8 \\
\hline & 99 & Alteromonadales & Seawater & 1 & 3 \\
\hline & 99 & Vibrionales & Coral Mucus & 2 & 5 \\
\hline & 99 & Vibrionales & Human gut & 1 & 3 \\
\hline & 96 & Campylobacterales & Coral Disease & 2 & 5 \\
\hline & 99 & Actinomycetales & Human gut & 1 & 3 \\
\hline & 98 & Acidobacteria & Terrestrial & 1 & 3 \\
\hline & 97 & Flavobacteriales & Coral Disease & 1 & 3 \\
\hline & 99 & Lactobacillales & Terrestrial & 1 & 3 \\
\hline & 99 & Lactobacillales & Human mouth & 1 & 3 \\
\hline & 96 & Lactobacillales & Human mouth & 2 & 5 \\
\hline & 100 & Bacillales & Human gut & 1 & 3 \\
\hline & 99 & Bacillales & Terrestrial & 1 & 3 \\
\hline
\end{tabular}

A 16S rRNA clone library was constructed from an individual larva collected at each of three developmental timepoints. Shown are the percent sequence similarities based on blastn against the nucleotide database at NCBI (http://blast.ncbi.nlm.nih.gov/) across 500 bp sequence. Closest known sequences that have been found previously in coral samples are highlighted. 
enzyme digests and 86 unique T-RFs in the RsaI digests. Across all of the specimens, in at least two of the three restriction digests, two T-RFs were present in $100 \%$ of the samples. The two fragment lengths in each restriction enzyme, based on identity assignment by MiCA3, represent species from Marinobacter and RCA bacteria. The T-RF lengths are consistent with predicted in silico digests of all of the Marinobacter sp. sequences and most of the Rhodobacterales sequences in the $16 \mathrm{~S}$ rRNA gene clone libraries from the specimens in this study.

MRPP analyses from all of the P. astreoides larval samples did not support significant differences among the 16S rRNA gene TRFLP profiles from

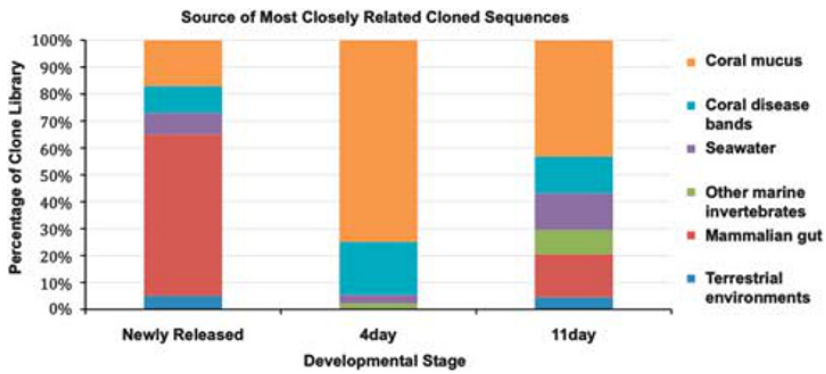

Figure 2 Phylogenetic affiliations and habitat classifications of bacterial sequences obtained from $P$. astreoides larvae. Cloned sequences, grouped by the $P$. astreoides developmental stage in which it was detected, show the origin of the closest sequence match, according to the RDP (Ribosomal Database Project) and BLAST (GenBank). The majority of the sequences from the newly released larva $(\sim 70 \%)$ are most closely related to bacteria previously found in mammals. Sequences with high similarity to those found in coral mucus and coral disease bands are prevalent in other samples, making up $90 \%$ of the sequences from the 4-day-old larva and $60 \%$ of the sequences from the 11-day-old polyp. Other categories, such as terrestrial environments, are not represented in sequences from all three of the stages. In libraries from each of the three developmental stages, only a small percentage $(5-10 \%)$ of sequences in the libraries match most closely to bacteria found in seawater. Also present in the libraries are sequences most closely affiliated with bacterial 16S rRNA gene sequences recovered from other marine organisms, including dinoflagellates and invertebrates. samples based on location of collection or developmental stage $(P=0.066$ and 0.439 , respectively; Figure 3, Table 3). MRPP suggested significant variation in bacterial community composition based on year of collection ( $P=0.004$; Figure 3, Table 3). A Fisher's exact test with false discovery rate controls was used to make pairwise comparisons of TRFLP profiles from samples based on collection year and to identify which peaks (taxa) drive the differences among samples. However, results of the Fisher's exact test with correction are evidence that none of the years significantly differed from one another (Table $4 ; q>0.05$ ).

\section{Discussion}

Consistent presence of bacterial cells in the ectoderm in all tested newly released $P$. astreoides larvae is evidence that $P$. astreoides transmits bacterial cells from the adult colonies to larvae. Vertical transmission of bacteria has been documented among diverse marine invertebrate phyla (Bright and Bulgheresi, 2010) including but not limited to bryozoans (Haygood and Davidson, 1997), sponges (Enticknap et al., 2006; Schmitt et al., 2007; Sharp et al., 2007), ascidians (Hirose, 2000) and bivalves (Cary, 1994; Krueger et al., 1996; Gros et al., 1999; Fiala-Medioni et al., 2002), but this is the first

Table 3 Multiresponse permutation procedure (MRPP) analysis of the three variables in the Porites astreoides samples

\begin{tabular}{lll}
\hline & P-value & A-value \\
\hline Location & 0.06661 & 0.05913 \\
Developmental stage & 0.43915 & 0.00204 \\
Year & $\mathbf{0 . 0 0 4 4 5 *}^{*}$ & 0.16882
\end{tabular}

For each of the three parameters (collection location, developmental stage and collection year), $P$-value and $A$-value statistics are shown. Values indicating significant differences $(P<0.05)$ are shown in bold with an asterisk.

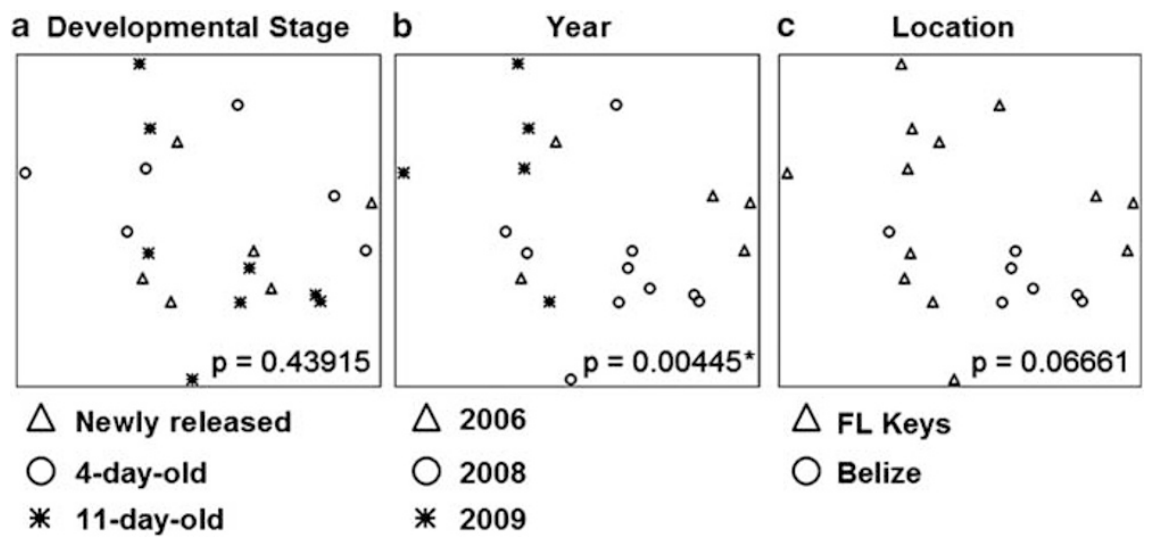

Figure 3 Results of MRPP ordination for bacterial community composition in P. astreoides larvae, based on 16S rRNA gene T-RFLP profiles. Ordination plots of T-RFLP profiles, according to the (a) developmental stage, (b) collection year and (c) collection location. Symbol shape represents different values for each parameter. 
Table 4 Pairwise comparisons (Fisher's exact test) on samples based on collection year, with false discovery correction

\begin{tabular}{lcc}
\hline & P-value & q-value \\
\hline 2006 vs 2008 & 0.0179 & 0.9648 \\
& 0.0179 & 0.9648 \\
& 0.0337 & 0.9648 \\
& 0.0357 & 0.9648 \\
& 0.0014 & 0.3393 \\
& 0.0048 & 0.3958 \\
& 0.0048 & 0.3958 \\
& 0.0128 & 0.6786 \\
& 0.0179 & 0.6786 \\
0.0256 & 0.6786 \\
& 0.0256 & 0.6786 \\
& 0.0256 & 0.6786 \\
& 0.0337 & 0.6786 \\
0.0357 & 0.6786 \\
& 0.0357 & 0.6786 \\
& 0.0357 & 0.6786 \\
& 0.0357 & 0.6786 \\
& 0.0079 & 0.1671 \\
& 0.0079 & 0.1671 \\
& 0.0079 & 0.1671 \\
& 0.0476 & 0.1671 \\
& 0.0476 & 0.1671 \\
& 0.0476 & 0.1671 \\
0.0476 & 0.1671 \\
0.0476 & 0.1671 \\
0.0476 & 0.1671 \\
& & \\
\hline & &
\end{tabular}

Pairwise comparisons with false discovery rate control were run on samples. The $q$-value indicates no significant differences among any peaks (bacterial taxa) from year to year. Shown are the $P$-values $(P<0.05)$ that indicated significant difference in the Fisher's exact test. Their corresponding $q$-values indicate no significant difference $(q>0.05)$.

evidence of transmission in scleractinian corals. The passage of bacteria from parent to offspring often indicates evolution of a long-term association between the coral and the vertically transmitted bacterial component. Though this study does not determine a function for larva-associated bacteria, it is likely that transmission reflects some level of selection and could indicate a potential for influence on host and/or symbiont fitness.

In this study, two complementary approaches, clone library construction and TRFLP analysis, were used to assess bacterial community composition. 16S rRNA gene clone libraries were constructed from only a single specimen of each host developmental stage to preserve any potential variability of bacterial community composition across individual larvae. The libraries, therefore, do not offer a comprehensive inventory of bacterial species or suggest trends in community variation across different developmental stages of $P$. astreoides. However, the libraries provide sequences from groups of bacteria of potential interest. TRFLP analysis can be performed on a larger array of samples-in this case, samples representing various life stages, collection years and locations. Cloned sequences can be digested in silico and used to identify fragments in TRFLP analysis. The combination of these comple- mentary approaches, which each has its limitations, is therefore critical for a comprehensive characterization of the bacterial communities across the sampled collection.

Littman et al. (2009a) suggest that bacterial community composition of 9-month-old juvenile Pacific Acroporid corals is highly variable and distinct from that of adults. In this study, TRFLP and cloned sequences indicated that bacterial groups consistently present in $P$. astreoides across multiple early developmental stages, collection locations and dates are closely related (96-98\% sequence similarity) to bacteria found in adult corals. Here we propose that planulae of $P$. astreoides, and possibly other corals, can be useful for identifying bacteria significant to the host, even throughout later stages of the host life cycle.

TRFLP analysis surveyed for the presence of bacterial ribotypes in samples of various stages, independent of their relative abundances in $16 \mathrm{~S}$ rRNA gene clone libraries. The TRFLP results suggest that two groups of ribotypes (Marinobacter and RCA group) are consistently present across all surveyed samples, even though they represent small portions of the cloned sequences from the sampled newly released larva. TRFLP analysis was also used to assess bacterial community diversity in $P$. astreoides samples across large spatiotemporal scales and early host development. Statistical analysis of the sampled TRFLP profiles did not support significant differences among the collected larvae. These data are consistent with previous studies suggesting that $P$. astreoides adult colonies maintain specific bacterial assemblages (Rohwer et al., 2002; Wegley et al., 2007).

The TRFLP results reveal other T-RFs corresponding to fragment lengths of Streptococcus, Moraxella and Haemophilus predicted by in silico digests. Though these fragments are not present in $100 \%$ of the sampled larvae, 16S rRNA gene sequences from these groups of bacteria were detected in the clone libraries of the newly released larvae, and TRFLP analysis suggests that they are present in over half of the tested samples, across all developmental stages, dates and locations of collections. In the clone library from the newly released larvae, the majority of the sequences are most highly affiliated (99-100\% sequence similarity) with sequences from bacterial strains of Haemophilus sp., Staphylococcus sp. and Streptococcus sp. previously isolated from human digestive and respiratory tracts. The origin of these bacteria is unknown, but because the coral larvae were collected in areas of high human presence, one possibility is that they are coming into contact with human-associated bacteria. However, the possibility that these sequences represent bacteria specifically associated with the corals themselves or other marine organisms cannot be excluded. Future use of sequence analysis and microscopy for detection of those specific groups of bacteria in larval and adult stages is necessary to understand how 
corals interact with genera such as Haemophilus, Staphylococcus and Streptococcus in the marine environment.

The Rhodobacterales sequences in this study primarily represent the RCA group of bacteria. It is not yet known how-or if-RCA bacteria affect fitness of the coral P. astreoides. In previous studies, the RCA bacterial group has been shown to have a diverse set of potential interactions, beneficial and detrimental, with the coral host. Further research is needed to assess whether the RCA detected in $P$. astreoides larvae can act as pathogens, commensals or mutually beneficial bacteria. Roseobacter is an abundant and diverse genus in seawater communities, notably in coral reef habitats and coral mucus (Piekarski et al., 2009), and Roseobacter are among the first bacterial associates acquired from seawater by larvae of the Pacific spawning coral Pocillopora meandrina (Apprill et al., 2009). Other RCA bacteria have been shown to exhibit antibacterial activity against known marine pathogens (Ritchie, 2006; Garren et al., 2009; Nissimov et al., 2009). Many RCA bacteria engage in associations with dinoflagellates in the marine environment (Biebl et al., 2005) and in laboratory culture (Lafay et al., 1995; Prokic et al., 1998; Miller and Belas, 2006). On the basis of the prevalence of chemotaxis toward dimethylsulfoniopropionate, a dinoflagellate metabolite, among RCA bacteria, it has been hypothesized that some RCA bacteria detected in corals are associated with Symbiodinium spp., though it is unknown whether this interpartner communication results in a fitness benefit to the Symbiodinium or to the coral host (Yoch, 2002; Miller et al., 2004; Miller and Belas, 2006). Though RCA bacteria in some corals may provide potential benefits to the coral holobiont, other RCA strains have been found to be pathogenic, implicated in coral black band disease (Sekar et al., 2008) and juvenile oyster disease (Boettcher et al., 2000). Ribotypes identified in the clone libraries are affiliated (98-99\% sequence similiarity) with RCA sequences derived from disease bands in the coral Siderastrea siderea (Sekar et al., 2006) and Thalassomonas sp. and Rhodobacter sp. (94-99\% sequence similarity) associated with disease bands in other corals. Future culture-independent work, including localization and quantification of specific bacteria and transcriptomic and proteomic analysis from coral larval samples, will help to determine whether RCA bacteria in $P$. astreoides exist as beneficial, pathogenic or commensal associates of the coral host, and whether environmental parameters can control the impact of RCA bacteria on coral fitness.

Another major group that TRFLP indicates is present in all tested samples is Marinobacter, a genus of bacteria known to exist both as free-living bacteria and in association with the surfaces of a broad range of marine eukaryotes. Cloned sequences found in the tested samples show high sequence affiliation (98-99\%) to Marinobacter sp. previously described in the mucus of multiple coral species distributed across the world. Though it is unknown whether Marinobacter sp. affects the fitness of the coral host or how that genus affects the fitness of its coral host, sequences affiliated with Marinobacter were recovered from the mucus of corals in the Caribbean (Rohwer et al., 2002) and the Australian Great Barrier Reef (Littman et al., 2010). Sequences representing Oceanospirillum sp. (97-99\% similarity) are a component of the $\gamma$-proteobacterial sequences in the libraries in this study. Though it is not well known whether Oceanospirillum sp. derives a benefit from association with corals or vice versa, the genus Oceanospirillum has been detected in many corals worldwide (Rohwer et al., 2002; Wegley et al., 2007; Sunagawa et al., 2009, 2010; Littman et al., 2009b) and appears to be a major component of $P$. astreoides adult colonies in the Florida Keys (K Morrow, personal communication). Meta-analysis of sequence data from coral-associated bacterial assemblages has been used to show that sequences from Oceanospirillales have been more frequently observed in healthy coral mucus than in diseased coral samples (Mouchka et al., 2010), but there is no functional link yet identified between Oceanospirillales and coral health.

In FISH imaging of the 11-day-old juvenile polyps, bacterial cells were detected adjacent to the tissues surrounding the developing septa (Figure 1), or the newly deposited calcium carbonate coral skeleton. Further research is needed to determine whether bacteria influence deposition of, or interact with, the developing carbonate skeleton in juveniles, or whether the epithelial tissue layer close to newly forming septa has other biochemical characteristics that attract and encourage aggregation of bacteria.

In the 16S rRNA gene clone libraries from the early developmental time series, the post-settlement life stage library possesses 27 ribotypes, more than the newly released larva or the 4-day-old larva (Table 2). These data are consistent with the hypothesis that upon release, larvae harbor a bacterial assemblage with only a few types of bacteria. After settlement and metamorphosis, coral tissues continue to differentiate, the juvenile deposits skeleton and the coral mucus layer on the surface of the juvenile polyp develops. These developmental changes in the coral tissue likely support more complex and varied niches, and as a result, colonization by a more diverse prokaryotic assemblage. The 16S rRNA gene clone libraries based on a small number of clones from a single specimen from each stage show differences in bacterial community composition throughout the different early host developmental stages. However, MRPP analysis and post-hoc pairwise comparisons (Fisher's exact tests with false discovery rate correction) on the TRFLP data from the larger, more comprehensive set of $P$. astreoides larval samples do not support significant differences in bacterial community composition 
among larval specimens according to location, developmental stage or year. This is in contrast to the observation that environmental parameters drive bacterial community composition in spawning coral species (Littman et al., 2010). Recent research shows that many spawning corals re-acquire bacteria from the environment each generation (Apprill et al., 2009; Sharp et al., 2010), but this study suggests that $P$. astreoides, a brooding coral, transmits bacteria to its offspring. It is possible that vertical transmission allows $P$. astreoides to maintain specific associations with certain bacteria, regardless of year or location of collection. This study identifies the RCA bacteria and Marinobacter groups, both detected consistently in all tested early life stages, as potential specific associates of $P$. astreoides.

High bacterial diversity associated with adult corals makes it challenging to identify which components are consistently associated with the host and ecologically significant to host survival. We propose that studying diversity and dynamics of bacterial communities in early life stages of corals may be more tractable and informative than adult colonies for addressing such questions. Our results indicate some continuity to bacterial community composition in $P$. astreoides across time and space during the early life history stages. Further research focusing on these specific groups of bacteria could help to quantify shifts in abundance of different bacterial groups throughout the life cycle of the host and in diseased and healthy states and to determine whether these patterns of diversity are preserved in adult colonies. Identification of these groups provides the groundwork for future research focusing on diversity and dynamics of bacterial communities in scleractinian corals. Further studies focusing on patterns of diversity of Rhodobacterales and Marinobacter in other coral host species will provide insight into general patterns of bacterial community composition and dynamics across a broad range of coral host species and are necessary for assessing the stability of coral-bacterial associations in the face of a changing global marine environment.

\section{Acknowledgements}

Funding was provided through a Smithsonian Marine Science Network Postdoctoral Fellowship to KHS and Mote Protect our Reefs Grants (POR-2007-15 and POR2009-16). KHS was supported by a postdoctoral research fellowship by the Philip Goelet Foundation and the Ocean Genome Legacy. We thank E Bartels and C Walter for their support of $P$. astreoides larval collection at Mote Marine Laboratory in the Florida Keys. In addition, we thank $\mathrm{R}$ Ritson-Williams for collection and maintenance of $P$. astreoides larvae in the Florida Keys and in Carrie Bow Cay, Belize. L Walters, K Ritchie, K Morrow, M Teplitski, C Krediet, B Engel, A Al-Agely, C Ross, K Grablow, $\mathrm{K}$ Arthur and $\mathrm{K}$ Semon assisted with $P$. astreoides larval collection and maintenance in the Florida Keys. We thank Margo Haygood at the Oregon Health and Sciences
University for providing access to a Zeiss LSM510 laser confocal scanning microscope system, on which some of the images were taken. The remaining micrographs were taken on a Zeiss LSM510 at the Smithsonian Marine Station at Fort Pierce. We also thank the Belize Fisheries Department for providing us permits and facilitating our research in Belize to work with coral larvae at Carrie Bow Cay, Belize. Coral larvae in the Florida Keys were collected under permits FKNMS-2006-034, FKNMS2008-018 and FKNMS-2009-031. This is contribution \#863 from the Smithsonian Marine Station at Fort Pierce and contribution \#910 from the CCRE program.

\section{References}

Altschul SF, Gish W, Miller W, Wyers EW, Lipman DJ. (1990). Basic local alignment search tool. J Mol Biol 215: 403-410.

Apprill A, Marlow HQ, Martindale MQ, Rappe MS. (2009). The onset of microbial associations in the coral Pocillopora meandrina. ISME J 3: 685-699.

Barott KL, Rodriguez-Brito B, Janouskovec J, Marhaver KL, Smith JE, Keeling P et al. (2011). Microbial diversity associated with four functional groups of benthic reef algae and the reef-building coral Montastraea annularis. Environ Microbiol 13: 1192-1204.

Ben-Haim Y, Rosenberg E. (2002). A novel Vibrio sp. pathogen of the coral Pocillopora damicornis. Mar Biol (Berlin) 141: 47-55.

Biebl H, Allgaier M, Tindall BJ, Koblizek M, Lunsdorf H, Pukall R et al. (2005). Dinoroseobacter shibae gen. nov., sp. nov., a new aerobic phototrophic bacterium isolated from dinoflagellates. Int J Syst Evol Microbiol 55: 1089-1096.

Boettcher KJ, Barber BJ, Singer JT. (2000). Additional evidence that juvenile oyster disease is caused by a member of the Roseobacter group and colonization of nonaffected animals by Stappia stellulata-like strains. Appl Environ Microbiol 66: 3924-3930.

Bright M, Bulgheresi S. (2010). A complex journey: transmission of microbial symbionts. Nat Rev Microbiol 8: 218-230.

Cary SC. (1994). Transovarial inheritance of endosymbiotic bacteria in the protobranch bivalve, Solemya reidi. EOS 75: 60.

Cole JR, Chai B, Marsh TL, Farris RJ, Wang Q, Kulam SA et al. (2003). The Ribosomal Database Project (RDP-II): previewing a new autoaligner that allows regular updates and the new prokaryotic taxonomy. Nucleic Acids Res 31: 442-443.

Enticknap JJ, Kelly M, Peraud O, Hill RT. (2006). Characterization of a culturable alphaproteobacterial symbiont common to many marine sponges and evidence for vertical transmission via sponge larvae. Appl Environ Microbiol 72: 3724-3732.

Fiala-Medioni A, McKiness ZP, Dando P, Boulegue J, Mariotti A, Alayse-Danet AM et al. (2002). Ultrastructural, biochemical, and immunological characterization of two populations of the mytilid mussel Bathymodiolus azoricus from the Mid-Atlantic Ridge: evidence for a dual symbiosis. Mar Biol (Berlin) 141: 1035-1043.

Frias-Lopez J, Bonheyo GT, Jin QS, Fouke BW. (2003). Cyanobacteria associated with coral black band 
disease in Caribbean and Indo-Pacific Reefs. Appl Environ Microbiol 69: 2409-2413.

Frias-Lopez J, Klaus JS, Bonheyo GT, Fouke BW. (2004). Bacterial community associated with black band disease in corals. Appl Environ Microbiol 70: 5955-5962.

Garren M, Raymundo L, Guest J, Harvell CD, Azam F. (2009). Resilience of coral-associated bacterial communities exposed to fish farm effluent. PLOS One 4: e7319.

Gros O, Duplessis MR, Felbeck H. (1999). Embryonic development and endosymbiont transmission mode in the symbiotic clam Lucinoma aequizonata (Bivalvia: Lucinidae). Invert Reprod Dev 36: 93-103.

Haygood MG, Davidson SK. (1997). Small-subunit rRNA genes and in situ hybridization with oligonucleotides specific for the bacterial symbionts in the larvae of the bryozoan Bugula neritina and proposal of 'Candidatus Endobugula sertula'. Appl Environ Microbio 63: 4612-4616.

Hirose E. (2000). Plant rake and algal pouch of the larvae in the tropical ascidian Diplosoma similis: an adaptation for vertical transmission of photosynthetic symbionts Prochloron sp. Zoolog Sci 17: 233-240.

Kline DI, Kuntz NM, Breitbart M, Knowlton N, Rohwer F. (2006). Role of elevated organic carbon levels and microbial activity in coral mortality. Mar Ecol Prog Ser 314: 119-125.

Knowlton N, Rohwer F. (2003). Multispecies microbial mutualisms on coral reefs: the host as a habitat. $\mathrm{Am}$ Nat 162: S51-S62.

Krueger DM, Gustafson RG, Cavanaugh CM. (1996). Vertical transmission of chemoautotrophic symbionts in the bivalve Solemya velum (Bivalvia: Protobranchia). Biol Bull 190: 195-202.

Kuffner IB, Walters LJ, Becerro MA, Paul VJ, RitsonWilliams R, Beach KS. (2006). Inhibition of coral recruitment by macroalgae and cyanobacteria. Marine Ecology Progress Series 323: 107-117.

Kushmaro A, Rosenberg E, Fine M, Loya Y. (1997). Bleaching of the coral Oculina patagonica by Vibrio AK-1. Mar Ecol Prog Ser 147: 159-165.

Lafay B, Ruimy R, Detraubenberg CR, Breittmayer V, Gauthier MJ, Christen R. (1995). Roseobacter aligicola sp. nov., a new marine bacterium isolated from the phycosphere of the toxin-producing dinoflagellate Prorocentum lima. Int J Syst Bacteriol 45: 290-296.

Lesser MP, Falcon LI, Rodriguez-Roman AR, Enriquez S, Hoegh-Guldberg O, R I-P. (2007). Nitrogen fixation by symbiotic cyanobacteria provides a source of nitrogen for the scleractinian coral Montastraea cavernosa. Mar Ecol Prog Ser 346: 143-152.

Lesser MP, Farrell JH. (2004). Exposure to solar radiation increases damage to both host tissues and algal symbionts of corals during thermal stress. Coral Reefs 23: 367-377.

Littman RA, Bourne DG, Willis BL. (2010). Responses of coral-associated bacterial communities to heat stress differ with Symbiodinium type on the same coral host. Mol Ecol 19: 1978-1990.

Littman RA, Willis BL, Bourne DG. (2009a). Bacterial communities of juvenile corals infected with different Symbiodinium (dinoflagellate) clades. Mar Ecol Prog Ser 389: 45-59.

Littman RA, Willis BL, Pfeffer C, Bourne DG. (2009b). Diversities of coral-associated bacteria differ with location, but not species, for three acroporid corals on the Great Barrier Reef. FEMS Microbiol Ecol 68: 152-163.

Loy A, Horn M, Wagner M. (2003). probeBase - an online resource for rRNA-targeted oligonucleotide probes. Nucleic Acids Res 31: 514-516.

McGuire MP. (1998). Timing of larval release by Porites astreoides in the northern Florida Keys. Coral Reefs 17: 369-375.

Miller TR, Belas R. (2006). Motility is involved in Silicibacter sp. TM1040 interaction with dinoflagellates. Environ Microbiol 8: 1648-1659.

Miller TR, Hnilicka K, Dziedzic A, Desplats P, Belas R. (2004). Chemotaxis of Silicibacter sp. strain TM1040 toward dinoflagellate products. Appl Environ Microbiol 70: 4692-4701.

Mouchka ME, Hewson I, Harvell CD. (2010). Coral-associated bacterial assemblages: current knowledge and the potential for climate-driven impacts. Integr Comp Biol 50: 662-674.

Negri AP, Webster NS, Hill RT, Heyward AJ. (2001). Metamorphosis of broadcast spawning corals in response to bacteria isolated from crustose algae. Mar Ecol Progr Ser 223: 121-131.

Nissimov J, Rosenberg E, Munn CB. (2009). Antimicrobial properties of resident coral mucus bacteria of Oculina patagonica. FEMS Microbiol Lett 292: 210-215.

Olson ND, Ainsworth TD, Gates RD, Takabayashi M. (2009). Diazotrophic bacteria associated with Hawaiian Montipora corals: diversity and abundance in correlation with symbiotic dinoflagellates. $J$ Exp Mar Biol Ecol 371: 140-146.

Patterson KL, Porter JW, Ritchie KE, Polson SW, Mueller E, Peters EC et al. (2002). The etiology of white pox, a lethal disease of the Caribbean elkhorn coral, Acropora palmata. Proc Natl Acad Sci USA 99: 8725-8730.

Piekarski T, Buchholz I, Drepper T, Schobert M, WagnerDoebler I, Tielen P et al. (2009). Genetic tools for the investigation of Roseobacter clade bacteria. $B M C$ Microbiol 9: 265.

Preston CM, Wu KY, Molinski TF, Delong EF. (1996). A psychrophilic crenarchaeon inhabits a marine sponge: Cenarchaeum symbiosum gen. nov., sp. nov. Proc Natl Acad Sci USA 93: 6241-6246.

Prokic I, Brummer F, Brigge T, Gortz HD, Gerdts G, Schutt $\mathrm{C}$ et al. (1998). Bacteria of the genus Roseobacter associated with the toxic dinoflagellate Prorocentrum lima. Protist 149: 347-357.

Ritchie KB. (2006). Regulation of microbial populations by coral surface mucus and mucus-associated bacteria. Mar Ecol Prog Ser 322: 1-14.

Rohwer F, Breitbart M, Jara J, Azam F, Knowlton N. (2001). Diversity of bacteria associated with the Caribbean coral Montastraea franksi. Coral Reefs 20: 85-91.

Rohwer F, Seguritan V, Azam F, Knowlton N. (2002). Diversity and distribution of coral-associated bacteria. Mar Ecol Prog Ser 243: 1-10.

Rosenberg E, Koren O, Reshef L, Efrony R, ZilberRosenberg I. (2007). The role of microorganisms in coral health, disease and evolution. Nat Rev Microbiol 5: $355-362$.

Rypien KL, Ward JR, Azam F. (2010). Antagonistic interactions among coral-associated bacteria. Environ Microbiol 12: 28-39.

Schmitt S, Weisz JB, Lindquist N, Hentschel U. (2007). Vertical transmission of a phylogenetically complex microbial consortium in the viviparous sponge Ircinia felix. Appl Environ Microbiol 73: 2067-2078. 
Sekar R, Kaczmarsky LT, Richardson LL. (2008). Microbial community composition of black band disease on the coral host Siderastrea siderea from three regions of the wider Caribbean. Mar Ecol Prog Ser 362: 85-98.

Sekar R, Mills DK, Remily ER, Voss JD, Richardson LL. (2006). Microbial communities in the surface mucopolysaccharide layer and the black band microbial mat of black band-diseased Siderastrea siderea. Appl Environ Microbio 72: 5963-5973.

Sharp KH, Eam BE, Faulkner DJ, Haygood MG. (2007). Vertical transmission of diverse microbes in the tropical sponge Corticium sp. Appl Environ Microbiol 73: 622-629.

Sharp KH, Ritchie KB, Schupp PJ, Ritson-Williams R, Paul VJ. (2010). Bacterial acquisition in juveniles of several broadcast spawning coral species. PLOS One 5: e10898.

Shyu C, Soule T, Bent SJ, Foster JA, Forney LJ. (1997). MiCA: a web-based tool for the analysis of microbial communities based on terminal-restriction fragment length polymorphisms of $16 \mathrm{~S}$ and $18 \mathrm{~S}$ rRNA genes. $J$ Microb Ecol 53: 562-570.

Storey JD. (2002). A direct approach to false discovery rates. J Roy Statistical Soc, Ser B 64: 490.
Sunagawa S, DeSantis TZ, Piceno YM, Brodie EL, DeSalvo MK, Voolstra CR et al. (2009). Bacterial diversity and White Plague disease-associated community changes in the Caribbean coral Montastraea faveolata. ISME J 3: $512-521$.

Sunagawa S, Woodley CM, Medina M. (2010). Threatened corals provide underexplored microbial habitats. PLOS One 5: 7.

Sweet M, Croquer A, Bythell J. (2011). Bacterial assemblages differ between compartments within the coral holobiont. Coral Reefs 30: 39-52.

Tebben J, Tapiolas DM, Motti CA, Abrego D, Negri AP, Blackall LL et al. (2011). Induction of larval metamorphosis of the coral Acropora millepora by tetrabromopyrrole isolated from a Pseudoalteromonas bacterium. PLOS One 6: e19082.

Wegley L, Edwards R, Rodriguez-Brito B, Liu H, Rohwer F. (2007). Metagenomic analysis of the microbial community associated with the coral Porites astreoides. Environ Microbiol 9: 2707-2719.

Yoch DC. (2002). Dimethylsulfoniopropionate: its sources, role in the marine food web, and biological degradation to dimethylsulfide. Appl Environ Microbiol 68: 5804-5815. 